\title{
Problematika Pembelajaran TOAFL Pada Mahasiswa Fakultas Ilmu Tarbiyah dan Keguruan IAIN Sulthan Thaha Saifuddin Jambi
}

\author{
Muhammad Qodri \\ IAIN Sulthan Thaha Saifuddin Jambi \\ e-mail: mqodri87@gmail.com
}

\begin{abstract}
This study aims to uncover the forms of TOAFL learning problems that occur in students of the Faculty of Tarbiyah and Teacher Training IAIN Sulthan Thaha Saifuddin Jambi, the causes and solutions to overcome these problems. This research is descriptive in nature using a qualitative approach. Data collection is done through interviews, observations, and documentation using snowball sampling techniques. The collected data are analyzed interactively through data reduction, data presentation, then drawing conclusions. Efforts to validate the data, researchers compared the observations with interviews and documentation, between the results of interviews with one informant with other informants with the same problem. The results of the study revealed that: 1) The form of TOAFL learning problems related to students is the difficulty in translating and understanding reading, poor vocabulary and weakness in mastering Arabic grammar. While the problems related to media and learning facilities are inadequate facilities and infrastructure, lack of use of learning media, minimal and difficulty in obtaining literature in the preparation of teaching materials to be presented. 2) The causes of TOAFL learning problems are: heterogeneous educational backgrounds of students, lack of interest and motivation to learn about TOAFL courses, low levels of student intelligence, and very little lecture time. 3) Efforts made to overcome these problems are by increasing motivation and interest in learning, giving attention and doing a lot of tamrinat (training), completing lecture facilities and facilities, utilizing existing lecture facilities and facilities, as well as getting around and increasing lecture time.
\end{abstract}

Keywords: Language learning problems, TOAFL learning, Arabic as foreign language

\begin{abstract}
Abstrak
Penelitian ini bertujuan untuk mengungkap bentuk problematika pembelajaran TOAFL yang terjadi pada mahasiswa Fakultas Ilmu Tarbiyah dan Keguruan IAIN Sulthan Thaha S Jambi, faktor penyebab dan solusi untuk mengatasi problematika tersebut. Penelitian ini bersifat deskriptif dengan menggunakan pendekatan kualitatif. Pengumpulan data dilakukan melalui wawancara, observasi, dan dokumentasi dengan menggunakan teknik snowball sampling. Data yang dikumpulkan dianalisis secara interaktif melalui reduksi data, penyajian data, kemudian penarikan kesimpulan. Usaha keabsahan data, peneliti membandingkan antara hasil pengamatan dengan wawancara serta dokumentasi, antara hasil wawancara dengan informan yang satu dengan informan lainnya dengan permasalahan yang sama. Hasil penelitian mengungkapkan bahwa: 1) Bentuk problematika pembelajaran TOAFL yang terkait dengan mahasiswa adalah kesulitan dalam menerjemahkan dan memahami bacaan, miskin kosakata dan lemah dalam penguasaan tata bahasa Arab. Sedangkan problematika yang terkait dengan media dan sarana pembelajaran adalah kurang memadai sarana dan prasarana, kurangnya penggunaan media pembelajaran, minim dan sulitnya memperoleh literatur dalam penyusunan bahan ajar yang akan disajikan. 2) Penyebab problematika pembelajaran TOAFL adalah: latar belakang pendidikan mahasiswa yang heterogen, kurangnya minat dan motivasi belajar terhadap mata kuliah TOAFL, tingkat kecerdasan mahasiswa yang rendah, serta waktu perkuliahan yang sangat kurang. 3) Upaya yang dilakukan untuk mengatasi problematika tersebut adalah dengan cara meningkatkan motivasi dan minat belajar, memberikan perhatian dan banyak melakukan tamrinat (latihan), melengkapi sarana dan fasilitas perkuliahan, memanfaatkan sarana dan fasilitas perkuliahan yang sudah ada, serta menyiasati dan menambah waktu perkuliahan.
\end{abstract}

Kata Kunci: Problem Pembelajaran Bahasa, Pembelajaran TOAFL, Bahasa Arab sebagai Bahasa Asing 


\section{Pendahuluan}

Bahasa punya peran penting dalam kelangsungan hidup manusia. Dengan bahasa, orang bisa mengungkapkan pesan, rasa, dan maksud pikirannya kepada orang lain. Mustafa al-Gulayain mengatakan bahwa bahasa adalah kata atau lafal yang digunakan oleh setiap orang untuk menyampaikan maksud atau kehendak mereka. ${ }^{1}$ Dengan demikian, bahasa Arab adalah kalimat atau kata yang digunakan oleh orang Arab dan selainnya untuk menyampaikan kehendak dan maksudnya. Sebagaimana kita ketahui, bahwa bahasa Arab adalah selain menjadi bahasa universal umat Islam di seluruh dunia juga sebagai bahasa ubudiyyah umat Islam. Sehingga bagi kalangan muslimin khususnya non-Arab, belajar bahasa Arab merupakan hal yang sangat penting. Juga bahasa Arab menjadi bahasa pengantar sumber hukum Islam yaitu al-Qur'an dan Hadis dan karya-karya lainnya. Oleh karena itu, untuk mempelajari dan menelaah sumber-sumber hukum dalam Islam dibutuhkan kepiawaian seseorang dalam bidang bahasa Arab.

Bahasa Arab merupakan bidang studi yang saat ini mulai dikembangkan dalam wadah lembaga pendidikan formal maupun nonformal. Wilayah nonformal digarap dalam lembaga pendidikan bernuansa Islami yang pembelajarannya dimulai dari tingkat dasar hingga tingkat atas. Sedangkan dalam wilayah formal, penguasaan bahasa Arab digarap dalam lembagalembaga pendidikan mulai dari kelas tingkat dasar (madrasah ibtidaiyah) hingga tingkat atas (madrasah aliyah), bahkan pembelajarannya berlanjut hingga ke perguruan tinggi (jamiah/kulliyah al-ulya).

IAIN Sulthan Thaha Saifuddin merupakan Perguruan Tinggi Agama Islam Negeri (IAIN STS) di Jambi yang menjadi tumpuan masyarakat agar dapat mencetak para sarjana muslim yang memiliki ilmu ke-Islaman yang luas dan mendalam. Fakultas Ilmu Tarbiyah dan Keguruan merupakan salah satu fakultas yang ada di lingkungan IAIN STS Jambi yang telah memiliki 9 jurusan/program studi, yaitu: Jurusan Pendidikan Agama Islam, Pendidikan Bahasa Arab, Manajemen Pendidikan Islam, Bahasa Inggris, Matematika, Fisika, Biologi, Pendidikan Guru Madrasah Ibtidaiyah, dan Pendidikan Guru Raudhatul Athfal.

Salah satu mata kuliah institut yang dipelajari di lembaga pendidikan ini adalah bahasa Arab. Karena pentingnya bahasa Arab, maka perguruan tinggi Islam negeri ini tidak hanya menyelenggarakan perkuliahan bahasa Arab reguler, melainkan juga menyelenggarakan kuliah bahasa Arab sebagai alat atau tes untuk mengukur kemampuan mahasiswa dalam menguasai bahasa Arab, baik secara lisan maupun tulisan atau yang lebih dikenal dengan TOAFL (Test of Arabic Langusge as Foreign Language). Seluruh mahasiswa tanpa terkecuali mereka harus mengikuti mata kuliah TOAFL, dan harus melampirkan sertifikat TOAFL ketika mau menempuh ujian akhir (munaqasyah) maupun saat mengurus ijazahnya.

Program ini diberlakukan oleh pihak kampus agar seluruh mahasiswanya memiliki kemampuan berbahasa Arab, mampu dalam berbicara dengan menggunakan bahasa Arab, dan mampu dalam membaca, menela'ah, dan memahami teks-teks berbahasa Arab dalam bentuk literatur, khususnya yang berkaitan dengan TOAFL.

${ }^{1}$ Lihat Mustafa al-Gulayaini, Jami' al-Durus al-'Arabiyyah, (Kairo: Maktabah al-Syuruq al-Duwaliyah, 
Temuan di lapangan bahwa pembelajaran TOAFL di Fakultas Ilmu Tarbiyah dan Keguruan IAIN STS Jambi memiliki problem. Diantaranya adalah: pertama, mahasiswa di masing-masing jurusan di Fakultas Ilmu Tarbiyah dan Keguruan sangat majemuk dan beragam. Kedua, dasar pengetahuan bahasa Arab mereka masih kosong. Ketiga, buku tadribat fi ikhtibarat al-kifayah al-lugawiyah atau buku untuk latihan-latihan TOAFL hanya didesain untuk menguasai TOAFL dan targetnya adalah kemampuan mahasiswa dalam menjawab soal-soal TOAFL. Buku ini, meskipun materi-materi latihannya mencakup seluruh kompetensi kebahasaan, tetapi di lapangan masih jauh dari ideal. Keempat, untuk istima' problemnya adalah masih belum tersedianya rekaman dari native atau orang Arab asli. Kelima, minim dan sulitnya memperoleh buku-buku atau literatur sebagai "materi mentah" untuk penyusunan buku ajar yang akan disajikan dalam perkuliahan. Dan sangat sulit menemukan buku-buku atau sumber belajar yang bisa dipergunakan sebagai bahan ajar. Sumber-sumber dan literatur kebahasaaraban masih relatif sangat kurang. ${ }^{2}$

\section{Pembelajaran TOAFL}

Pembelajaran merupakan suatu kombinasi yang tersusun meliputi unsur-unsur manusiawi, material, fasilitas, perlengkapan, dan prosedur yang saling mempengaruhi mencapai tujuan pembelajaran. ${ }^{3}$ Menurut Wina Sanjaya pembelajaran merupakan proses berfikir yang menekankan kepada mencari dan menemukan pengetahuan melalui interaksi antara individu dengan lingkungan. ${ }^{4}$ Sedangkan Mukhtar berpendapat bahwa pembelajaran adalah proses interaksi peserta didik dengan pendidik dan sumber belajar pada suatu lingkungan belajar. ${ }^{5}$

Berdasarkan teori diatas, dapat dipahami bahwa pembelajaran adalah bagaimana mengelola lingkungan agar terjadi tindak belajar yang efektif dan efesien yang meliputi unsur-unsur tertentu dan prosedur untuk membantu siswa dalam mencapai tujuan. Oleh karena itu dalam proses belajar mengajar antara pendidik dan peserta didik harus ada saling interaksi yang baik, apalagi pada mata pelajaran Bahasa Arab, karena Bahasa Arab bisa dikatakan sebagai bahasa Asing bagi peserta didik. Jadi seorang pendidik dalam menyampaikan materi pelajaran Bahasa Arab harus bisa menguasai kelas serta dapat menjadikan suasana kelas menjadi menarik dan menyenangkan bagi peserta didik.

TOAFL atau kepanjangan dari Test of Arabic as a Foreign Language merupakan sebuah tes yang sudah terstandarisasi untuk menguji kemampuan bahasa Arab seseorang dari berbagai kemahiran; kemahiran membaca, mendengar, menulis dan analisis gramatikal Arab dan tata bahasanya. ${ }^{6}$ Tentunya untuk mengerjakannya membutuhkan kecakapan bahasa Arab yang memadai. Sebab, tanpa memiliki kemampuan dasar tersebut maka dapat dipastikan kemampuan menganalisis dan mengerjakannya tidak bisa maksimal. Oleh karenanya sangat

\footnotetext{
${ }^{2}$ Observasi, 5 Mei 2015.

${ }^{3}$ Lihat Omar Hamalik, Kurikulum dan Pembelajaran, (Jakarta: Bumi Aksara, 1995), h. 57.

${ }^{4}$ Lihat Wina Sanjaya, Pembelajaran Dalam Implementasi Kurikulum Berbasis Kompetensi, (Jakarta: PT Prenada Media Group, 2006), h. 83.

${ }^{5}$ Mukhtar, Desain Pembelajaran Pendidikan Agama Islam, (Jakarta: Misaka Galiza, 2003), h. 13.

${ }^{6}$ Mohammad Barmawi, Lulus TOAFL dengan Mudah dan Memuaskan, (Yogyakarta: PT.Diva Press Anggota IKAPI, 2011), h. 115.
} 
dianjurkan sebelum mengerjakan TOAFL, untuk memahami gramatikal bahasa Arab dan sering melatih ketangkasan berfikir dengan cara membaca teks-teks berbahasa Arab. Sehingga, bisa untuk maksimal dan tidak menemui kesalahan dalam menjawab dan menyelesaikan soal-soal Tes TOAFL.

Adapun materi TOAFL meliputi ilmu kebahasaaraban mencakup gramatika bahasa Arab (ilmu nahwu, ilmu shoraf, ilmu balaghah), mufradat, ibarat istilahiyyah/mahfudhzat, tarakib dan linguistik.

Tujuan diadakannya standarisasi penilaian kelulusan bahasa Arab untuk program sarjana (S-1), program magister (S-2) maupun doktoral (S-3) untuk menetapkan norma-norma keterampilan bahasa Arab yang kelak dijadikan sebagai pedoman standarisasi kelulusan bahasa Arab. Disamping itu juga, bertujuan untuk memberlakukan standar baku kelulusan bahasa Arab dalam TOAFL, dan untuk meningkatkan kualitas kemampuan dan penggunaan bahasa Arab bagi lulusan program S-1, S-2, S-3 di seluruh lembaga pendidikan di bawah naungan Kementerian Agama. ${ }^{7}$

\section{Keterampilan Bahasa Arab dalam TOAFL}

Bahasa Arab sebagaimana bahasa-bahasa yang lain memiliki empat keterampilan berbahasa (مهارة اللغة) atau dikenal dengan فنون اللغة (seni-seni bahasa). Dengan menggunakan kata maharah dapat dipahami bahwa aspek paling mendasar dari bahasa itu adalah alat komunikasi, dan keterampilan adalah bagian yang paling mendasar ketika menggunakan bahasa. Keempat maharah itu adalah: keterampilan mendengar (maharah al-istima'), keterampilan berbicara (maharah al-kalam), keterampilan membaca (maharaah al-qira'ah), dan keterampilan menulis (maharah al-kitabah). ${ }^{8}$

a. Kemampuan Mendengar

Adapun tes yang diujikan dalam keterampilan mendengar terdiri atas tiga kriteria, yaitu: pertama, keterampilan mendengar dan memahami pernyataan. Kedua, keterampilan mendengar dan memahami dialog. Ketiga: keterampilan dalam mendengar dan memahami teks.

1. Fahmut Tarakib wal Ibarat (Memahami Struktur Kalimat dan Ungkapan)

Ada beberapa klasifikasi tes yang diujikan dalam bagian pemahaman struktur kalimat dan ungkapan, yaitu: pertama, seputar keterampilan memahami kelengkapan struktur kalimat. Kedua, keterampilan memahami kesalahan penggunaan struktur kalimat melalui analisis kesalahan. Ketiga, keterampilan memahami ungkapan bahasa Arab dengan bahasa Indonesia

2. Fahmul Mufradat wa al-Nash al-Maktub (Memahami kosakata dan teks bahasa Arab)

Pada tes ini dituntut untuk benar-benar memahami kosa kata dalam struktur kalimat. Soal-soal yang disediakan ialah berkaitan dengan sinonim. Selain itu, soalsoal juga berkaitan dengan teks, dan diakhiri dengan tes pemahaman gramatikal

\footnotetext{
${ }^{7}$ Mohammad Barmawi, Lulus TOAFL dengan Mudah dan Memuaskan, h. 11.

${ }^{8}$ Lihat Imam Makruf, Strategi Pembelajaran Bahasa Arab Aktif, (Semarang: Pt. Need's Press, 2009), h. 18 .
} 
bahasa Arab. Adapun klasifikasi soal dalam memahami arti kosakata dan tulisan bahasa Arab, yaitu: memahami arti kosakata dalam sebuah kalimat, memahami isi teks atau wacana, dan memahami gramatikal bahasa Arab (ilmu nahwu dan ilmu shoraf) berdasarkan teks. ${ }^{9}$

\section{Metode Penelitian}

Penelitian ini bersifat deskriptif dengan menggunakan pendekatan kualitatif. Untuk mendukung pendekatan tersebut, maka pengumpulan datanya dilakukan melalui wawancara, observasi, dan dokumentasi dengan menggunakan teknik snowball sampling. Selanjutnya data yang dikumpulkan dianalisis secara interaktif melalui langkah reduksi data, penyajian data, dan penarikan kesimpulan. Usaha keabsahan data, peneliti melakukannya dengan membandingkan antara hasil pengamatan dengan wawancara serta dokumentasi, antara hasil wawancara dengan informan yang satu dengan informan lainnya dengan permasalahan yang sama.

\section{Hasil dan Pembahasan}

\section{Bentuk Problematika Pembelajaran TOAFL pada Mahasiswa FITK IAIN STS Jambi}

a. Berkaitan dengan Mahasiswa

1. Kesulitan dalam menterjemahkan dan memahami qira'ah

Salah satu materi yang disajikan dalam TOAFL yang sangat sulit dirasakan oleh mahasiswa adalah materi tarjamah dan memahami teks bacaan dalam bahasa Arab, dengan alasan susunan subjek dan predikat antara bahasa arab dengan terjemahnya sering dibalik/tidak urut. pengamatan penulis terhadap mahasiswa ketika dalam proses pembelajaran TOAFL dimana ada sebagian mahasiswa yang membaca teks arab pun masih kesulitan, bacaannya kurang lancar, apalagi untuk menterjemahkan dan memahami qira'ah tersebut. ${ }^{10}$

2. Miskin Mufradat

Berbagai problema yang dihadapi mahasiswa dalam mengikuti pembelajaran TOAFL, antara lain mengenai miskinnya kosakata atau mufradat. Kosakata adalah himpunan kata yang diketahui oleh seseorang atau entitas lain, atau merupakan bagian dari suatu bahasa tertentu. Kosakata dalam bahasa Inggris disebut vocabulary, kosakata seseorang didefinisikan sebagai himpunan semua kata-kata yang dimengerti oleh orang tersebut atau semua kata-kata yang kemungkinan akan digunakan oleh orang tersebut untuk menyusun kalimat baru

Kekayaan kosakata seseorang secara umum dianggap merupakan gambaran dari intelejensi atau tingkat pendidikannya. Karenanya banyak ujian standar yang memberikan pertanyaan yang menguji kosakata. Penambahan kosakata seseorang secara umum dianggap merupakan bagian penting, baik dari proses pembelajaran suatu bahasa ataupun pengembangan kemampuan seseorang dalam suatu bahasa yang sudah dikuasai. Murid sekolah sering diajarkan kata-kata baru sebagai bagian dari

\footnotetext{
${ }^{9}$ Lihat Imam Makruf, Strategi Pembelajaran Bahasa Arab Aktif, h. 28.

${ }^{10}$ Observasi, 7 Mei 2015
} 
mata pelajaran tertentu dan banyak pula orang dewasa yang menganggap pembentukan kosakata sebagai suatu kegiatan yang menarik dan edukatif (Wikipedia).

3. Lemah dalam penguasaan tata bahasa Arab

Tata bahasa adalah sintaksis yaitu ilmu menyusun kalimat sehingga kaidahnya mencakup hal-hal lain disamping i'rab, juga kesesuaian antara mubtada' (subyek) dengan khabar (predikat) dan antara sifat dan mausuf. Maksud dari kesesuaian disini adalah kesesuaian dalam segi jenis kelamin, bilangan. Dari contoh diatas dapat dilihat bahwa dalam tata kata seperti fi'il harus terletak didepan fa'il dan khabar harus sesuai dengan mubtada'nya baik dari segi jenis kelamin dan bilangan, khabar harus terletak sesudah mubtada', kecuali apabila khabar itu jar majrur maka boleh atau wajib mendahului mubtada'hal seperti ini tidak terdapat dalam gramatikal bahasa Indonesia.

Ada beberapa hal yang menjadi kesulitan dalam penguasaan kosa kata Arab, yaitu banyak sei morfologi yang tidak terjadi dalam bahasa Indonesia misalnya dari segi konjungsi (tashrif). Sebagai contoh fi'il madhi fa'ala untuk bentuk mudhori'nya menjadi yaf'ulu untuk amar menjadi uf'ul dan seterusnya. Selain itu untuk kata benda dalam bahasa Indonesia ada tunggal dan jamak, sedangkan dalam bahasa Arab ada tunggal, mutsanna, jamak mudzakar salim, jamak taktsir dan lain-lain.

b. Berkaitan dengan media dan sarana pembelajaran

1. Sarana dan prasarana yang ada kurang memadai

Problematika pembelajaran TOAFL adalah sarana ataupun media yang masih kurang sehingga kesulitan memanfaatkannya saat mengajar, kemudian kalaupun ada jarang digunakan oleh dosen yang bersangkutan sebagai alat bantu mengajar di ruang kelas pada pembelajaran TOAFL.

Fasilitas yang dimiliki dalam menunjang perkuliahan masih terbatas antara lain CD, infokus dan buku bahasa Arab seperti buku Tadribat fi Ikhtibarat al-Kifayah alLugawiyyah atau buku untuk latihan-latihan TOAFL. Buku ini, meskipun materimateri latihannya mencakup seluruh kompetensi kebahasaan, tetapi di lapangan masih jauh dari ideal, begitu juga dengan kaset bahasa Arab yang jarang digunakan dalam pembelajaran. Sedangkan mahasiswa jarang dibawa ke labor bahasa. Padahal ini penting, karena dengan laboratorium bahasa siswa dapat belajar mendengarkan dan berbicara serta kemahiran lain berbahasa dengan konsentrasi dan anak akan terfokus pada pembelajaran.

2. Media pembelajaran yang ada jarang digunakan

Penggunaan media pembelajaran dalam proses belajar mengajar dapat membangkitkan keinginan dan minat yang baru, membangkitkan motivasi dan rangsangan kegiatan belajar dan bahkan membawa pengaruh-pengaruh pada psikologis terhadap pembelajar. Berdasarkan hasil observasi penulis bahwa dalam pembelajaran TOAFL sangat diperlukan sekali media pembelajaran seperti infokus, 
serta pembelajaran di labor bahasa, akan tetapi dosen yang mengajar TOAFL jarang menggunakan fasilitas tersebut. ${ }^{11}$

3. Minim dan sulitnya memperoleh literatur.

Minimnya literatur sebagai materi mentah dalam menyusun bahan ajar yang akan disajikan di dalam perkuliahan. serta sulit menemukan buku-buku atau sumber belajar yang bisa digunakan sebagai bahan ajar. Ironisnya lagi, perpustakaan sebagai jantung perguruan tinggi yang ada belum begitu banyak menyediakan buku yang isinya bisa digunakan sebagai bahan ajar TOAFL. Sampai saat ini, ketersediaan bukubuku tentang bahasa atau kebahasaan, buku-buku pembelajaran bahasa di perpustakaan masih sangat sedikit. Sumber-sumber dan literatur kebahasaaraban masih relatif sangat kurang.

\section{Faktor Penyebab Problematika Pembelajaran TOAFL pada Mahasiswa FITK IAIN STS Jambi}

Terjadinya problematika atau permasalahan serta kesulitan pada mahasiswa FTIK IAIN STS Jambi dalam belajar TOAFL karena berbagai hal, yaitu sebagai berikut:

a. Latar belakang pendidikan mahasiswa yang heterogen

Salah satu faktor penyebab terjadinya permasalahan serta kesulitan dalam pembelajaran TOAFL adalah karena latar belakang pendidikan mahasiswa yang berbeda-beda. Ada yang tamatan dari SMU, ada yang tamatan Madrasah Aliyah atau pesantren. Yang berlatar belakang dari madrasah Aliyah atau pesantren, mereka dengan mudah menyerap mata kuliah tersebut. Sementara yang tamat dari SMU akan mengalami kesulitan dalam mengikuti pembelajaran TOAFL.

b. Kurangnya minat dan motivasi belajar terhadap mata kuliah TOAFL

Motivasi belajar seseorang bisa timbul dari dalam dirinya sendiri, mahasiswa menemukan hal-hal baru yang masih sangat sulit mereka terima, mengakibatkan mereka tidak ada motivasi untuk mempelajari bahasa Arab. Belajar atau menguasai bahasa ibu adalah sesuatu yang sangat vital dalam kehidupan manusia. Sebab, tergantung kepada keterampilan berbahasa itulah keperluan hidupnya dapat terpenuhi dan keinginannya dapat diraih.

Dengan demikian motivasi yang mendorong peserta didik untuk mempelajari bahasa orang-orang yang ada di sekitarnya merupakan motivasi intrinsik yang menjadikan belajar bahasa ibu merupakan tuntutan yang tidak bisa ditawar-tawar lagi dan menjadi suatu keharusan untuk memenuhi kebutuhan hidup dan mencapai tujuan akhir. Sementara kalau kita amati motivasi yang ada pada peserta didik yang belajar Bahasa Arab, motivasinya adalah bersifat ekstrinsik, sebab keinginan yang ingin dicapai dengan bahasa itu bersifat sementara bahkan hanya ilusi. Peneliti berasumsi bahwa mahasiswa kurang termotivasi untuk belajar TOAFL.

c. Tingkat kecerdasan mahasiswa yang rendah

\footnotetext{
${ }^{11}$ Observasi, 15 Mei 2015
} 
Kecerdasan peserta didik dalam satu tingkat kelas memang sangat beragam, hal ini menjadi masalah yang tidak mungkin bisa dihindari, karena sistem penerimaan mahasiswa baru tidak memungkinkan untuk melakukan penyaringan sehingga mahasiswa yang masuk dan diterima di kampus ini nyaris dengan tingkat kecerdasan yang sangat kontras. Di ruang kelas dosen akan berhadapan dengan sejumlah mahasiswa yang latar belakang kehidupannya yang berbeda, dan memiliki daya serap terhadap materi perkuliahan yang berbeda pula.

d. Waktu perkuliahan yang sangat kurang

Setiap materi perkuliahan tetntu memiliki tingkat kesukaran yang bervariasi. Pada satu sisi ada bahan perkuliahan yang tidak memerlukan kreativitas dosen, tetapi di lain pihak ada bahan perkuliahan yang sangat memerlukan kreativitas dosen. Bahan perkuliahan dengan tingkat kesukaran yang tinggi tentu sukar di proses oleh peserta didik. Apalagi bagi peserta didik yang kurang menyukai bahan perkuliahan yang disampaikan itu.

\section{Upaya Untuk Mengatasi Problematika Pembelajaran TOAFL pada Mahasiswa FTIK IAIN STS Jambi}

a. Meningkatkan motivasi dan minat belajar

Setiap perbuatan, termasuk perbuatan belajar didorong oleh satu atau beberapa motif. Motif atau biasa juga disebut juga dorongan atau kebutuhan merupakan suatu tenaga yang berada pada diri individu atau mahasiswa yang mendorongnya untuk berbuat mencapai suatu tujuan. Dari observasi peneliti lakukan terlihat bahwa sesungguhnya dosen TOAFL telah memberikan motivasi kepada mahasiswanya, akan tetapi masih perlu ditingkatkan dan hendaknya dilengkapi dengan metode mengajar yang bervariasi, yakni tidak menoton dengan satu teknik mengajar saja. Dengan adanya variasi mengajar ini diharapkan mahasiswa akan mampu berusaha untuk belajar lebih giat, dan termotivasi sehingga memberikan peluang kepada mahasiswa untuk lebih baik dari sebelumnya. $^{12}$

b. Memberikan Perhatian dan Banyak Tamrinat

Tingkat kecerdasan yang rendah yang dimiliki oleh sebagian mahasiswa merupakan salah satu problematika yang berkaitan dengan kesulitan belajar, sehingga mahasiswa kesulitan dalam mengikuti kegiatan perkuliahan di kelas. Untuk mengatasi kondisi yang demikian, diperlukan perhatian khusus dari dosen.Dosen berusaha memberikan bantuan khusus, misalnya dengan mengadakan program remedial teaching, melakukan bimbingan kepada mahasiswa secara kontinyu dengan memberikan banyak tamrinat di kelas, dan menghafal mufradat yang ada disekitar kampus.

c. Melengkapi Sarana dan Fasilitas Perkuliahan

Melengkapi sarana dan fasilitas perkuliahan merupakan suatu keharusan yang tidak boleh ditawar oleh lembaga pendidikan manapun agar dapat relevan dengan kondisi dan situasi masyarakat pada saat sekarang yang semakin maju khususnya dalam

\footnotetext{
${ }^{12}$ Observasi, 20 Mei 2015
} 
bidang teknologi informasi. Keberhasilan perkuliahan tidak lepas dari tersedianya sarana dan fasilitas yang memadai. Namun untuk memenuhi kebutuhan akan sarana dan fasilitas yang lengkap dan memadai, seperti labor bahasa, alat peraga multimedia, dibutuhkan investasi yang besar. Fasilitas atau alat-alat perlengkapan kuliah yang kurang lengkap membuat penyajian perkuliahan yang kurang baik, terutama yang sifatnya istima', kekurangan media dan fasilitas perkuliahan akan banyak menimbulkan kesulitan dalam pembelajaran. Dengan demikian alat-alat pembelajaran turut menentukan motivasi kerja dosen dalam mengajar.

d. Memanfaatkan Sarana dan Fasilitas perkuliahan yang sudah ada

Setiap materi perkuliahan tentu memiliki tingkat kesukaran yang bervariasi. Pada satu sisi ada bahan perkuliahan yang tidak memerlukan kreativitas dosen, tetapi di lain pihak ada bahan perkuliahan yang sangat memerlukan kreativitas dosen. Bahan perkuliahan dengan tingkat kesukaran yang tinggi tentu sukar di proses oleh peserta didik. Apalagi bagi peserta didik yang kurang menyukai bahan perkuliahan yang disampaikan itu.

Problematika dalam pembelajaran TOAFL khususnya yang berkaitan dengan sarana dan prasarana adalah dalam pemanfaatan sarana perkuliahan yang sudah ada, baik yang sederhana maupun yang membutuhkan keahlian khusus seperti alat audio visual dan multimedia. Sementara ini masih ada guru yang kurang memperhatikan pentingnya alat audio visual dalam kegiatan perkuliahan. Hal ini bisa saja karena dosen tersebut tidak biasa menggunakan alat audio visual, walaupun alat peraga yang sederhana dan sudah tersedia seperti LCD Proyektor, gambar-gambar dan lain sebagainya, atau bisa juga seorang dosen tidak menguasai cara menggunakan alat audio visual tersebut.

\section{Simpulan}

Berdasarkan pada pembahasan di atas, peneliti dapat menyimpulkan bahwa:

1. Pembelajaran TOAFL pada Fakultas Ilmu Tarbiyah dan Keguruan IAIN STS Jambi dihadapkan pada sejumlah problem yang berkaitan dengan mahasiswa dan media serta sarana pembelajaran. Adapun bentuk problematika pembelajaran TOAFL yang berkaitan dengan mahasiswa antara lain yaitu kesulitan dalam menterjemahkan dan memahami qira'ah, miskin mufradat atau kosakata, lemah dalam penguasaan tata bahasa Arab sementara problem yang berkaitan dengan media dan sarana pembelajaran yaitu sarana dan prasarana yang ada kurang memadai, media pembelajaran yang ada jarang digunakan, minim dan sulitnya memperoleh literatur dalam penyusunan bahan ajar yang akan disajikan di dalam perkuliahan.

2. Problematika di dalam mempelajari TOAFL sebagai tes bahasa asing memang bukan perkara yang baru mangingat bahasa adalah unsur budaya yang bersifat universal sehingga sudah sejak lama dikenal baik teori maupun permasalahannya oleh umat manusia. Terjadinya problematika serta kesulitan dalam belajar TOAFL, penyebabnya beragam, antara lain : latar belakang pendidikan mahasiswa yang heterogen, kurangnya 
minat dan motivasi belajar terhadap mata kuliah TOAFL, tingkat kecerdasan mahasiswa yang rendah, serta waktu perkuliahan yang sangat kurang.

3. Upaya yang dilakukan untuk mengatasi permasalahan dalam pembelajaran TOAFL antara lain dengan cara meningkatkan motivasi dan minat belajar, memberikan perhatian dan banyak tamrinat, melengkapi sarana \& fasilitas perkuliahan, memanfaatkan sarana dan fasilitas perkuliahan yang sudah ada, serta mensiasati dan menambah waktu perkuliahan. ${ }^{[]}$

\section{Daftar Rujukan}

Barmawi, Mohammad, Lulus TOAFL dengan Mudah dan Memuaskan, Yogyakarta: PT.Diva Press Anggota IKAPI, 2011.

Al-Gulayaini, Mustafa, Jami' al-Durus al-'Arabiyyah, Kairo: Maktabah al-Syuruq alDuwaliyah, 2008.

Hamalik, Omar, Kurikulum dan Pembelajaran, Jakarta: Bumi Aksara, 1995.

Makruf, Imam, Strategi Pembelajaran Bahasa Arab Aktif, Semarang: Pt. Need's Press, 2009.

Mukhtar, Desain Pembelajaran Pendidikan Agama Islam, Jakarta: Misaka Galiza, 2003.

Sanjaya, Wina, Pembelajaran Dalam Implementasi Kurikulum Berbasis Kompetensi, Jakarta: PT Prenada Media Group, 2006. ${ }^{[]}$ 